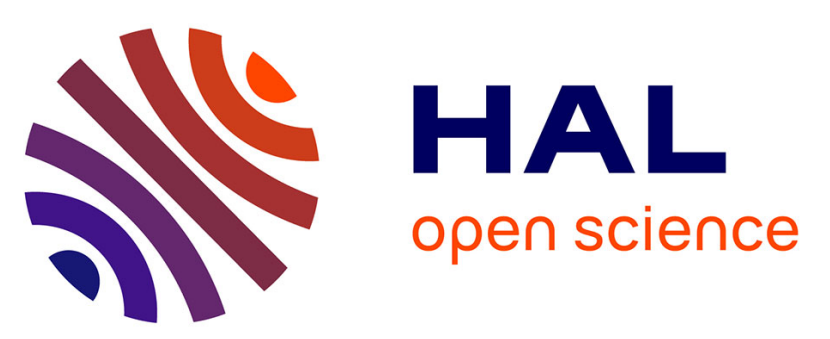

\title{
Vegetation and climate change during the Medieval Climate Anomaly and the Little Ice Age on the southern Cape coast of South Africa: pollen evidence from Bo Langvlei
}

Nadia Du Plessis, Brian M. Chase, Lynne Quick, Torsten Haberzettl, Thomas Kasper, Michael Meadows

\section{To cite this version:}

Nadia Du Plessis, Brian M. Chase, Lynne Quick, Torsten Haberzettl, Thomas Kasper, et al.. Vegetation and climate change during the Medieval Climate Anomaly and the Little Ice Age on the southern Cape coast of South Africa: pollen evidence from Bo Langvlei. The Holocene, 2020, 10.1177/0959683620950444 . hal-02935459

\section{HAL Id: hal-02935459 \\ https://hal.science/hal-02935459}

Submitted on 10 Sep 2020

HAL is a multi-disciplinary open access archive for the deposit and dissemination of scientific research documents, whether they are published or not. The documents may come from teaching and research institutions in France or abroad, or from public or private research centers.
L'archive ouverte pluridisciplinaire HAL, est destinée au dépôt et à la diffusion de documents scientifiques de niveau recherche, publiés ou non, émanant des établissements d'enseignement et de recherche français ou étrangers, des laboratoires publics ou privés. 
Vegetation and climate change during the Medieval Climate Anomaly and the Little Ice Age on the southern Cape coast of South Africa: pollen evidence from Bo Langvlei

\section{The authors do not recommend the distribution of this version of this article. The article is freely available upon request. \\ To receive a copy, please send a request to Brian Chase at: brian.chase@umontpellier.fr}

Nadia du Plessis ${ }^{1}$, Brian M. Chase ${ }^{1,2}$, Lynne J. Quick ${ }^{3}$, Torsten Haberzettl ${ }^{4}$, Thomas Kasper $^{5}$, Michael E. Meadows $^{1,6}$

${ }^{1}$ Department of Environmental and Geographical Science, University of Cape Town, South Lane, Upper Campus, 7701

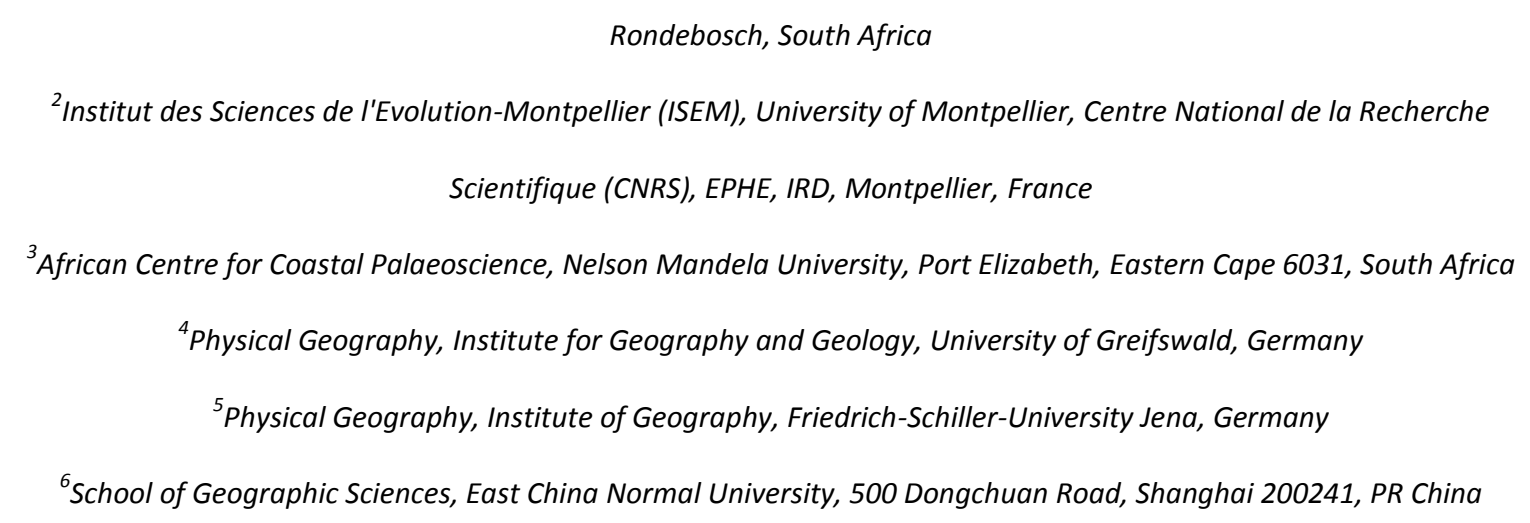

Corresponding author: Nadia du Plessis; dup.nadia@gmail.com

Keywords: palaeoecology, palaeoclimate, late Holocene, South Africa, pollen 
This paper presents continuous, high resolution fossil pollen and microcharcoal records from Bo Langvlei, a lake in the Wilderness Embayment on South Africa's southern Cape coast. Spanning the past $\sim 1300$ years and encompassing the Medieval Climate Anomaly (MCA; c. AD $950-1250$ ) and the Little Ice Age (LIA; C. AD 1300 - 1850), these records provide a rare southern African perspective on past temperature, moisture and vegetation change during these much debated periods of the recent geological past. Considered together with other records from the Wilderness Embayment, we conclude that conditions in the region during the MCA chronozone were - in the context of the last 1300 years - likely relatively dry (reduced levels of Afrotemperate forest pollen) and perhaps slightly cooler (increased percentages of Stoebe-type pollen) than present. The most significant phase of forest expansion, and more humid conditions, occurred during the transition between the MCA and the most prominent cooling phase of the LIA. The LIA is clearly identified at this locality as a period of cool, dry conditions between c. AD 1600 to c. AD 1850.

The mechanisms driving the changes observed in the Bo Langvlei pollen record appear to be generally linked to changes in temperature, and changes in the influence of tropical circulation systems. During warmer periods, moisture availability was higher at Bo Langvlei, and rainfall was perhaps less seasonal. During colder periods, precipitation resulting from tropical disturbances was more restricted, resulting in drier conditions. While increased precipitation has been reported during the LIA from Verlorenvlei in the Western Cape as a result of an equatorward displacement of the westerly storm-track at this time, the opposing response at Bo Langvlei suggests that any increased influence of westerlies was insufficient to compensate for the concurrent reduction in tropical/local rainfall in the region. 
51 To understand the nature and challenges of climate change in southern Africa it is important to establish an understanding of natural variability in the recent geological past. Two key periods characterize the climate since AD 650: the Medieval Climate Anomaly (MCA; C. AD $950-1250$ ) and the Little Ice Age (LIA; c. AD 1300 - 1850) (Jones et al., 2001; Matthews and Briffa, 2005). While recognized as not being robust features in proxy records from all regions of the globe (e.g. PAGES2k 2013; Neukom et al. 2019), the study of these periods provides an important context for modern and predicted future climate states.

It is well documented that the South African palaeoenvironmental record is relatively limited in terms of both the quantity and quality of records compared with the mid-latitudes of the Northern Hemisphere (see Chase and Meadows 2007), where the MCA and LIA have been defined. This is mainly due to the region's highly seasonal rainfall regimes and generally arid to semi-arid environments, which are not conducive to the preservation of sedimentary sequences and associated proxy records. Recent reviews by Nicholson et al. (2013), Nash et al. (2016) and Lüning et al. $(2017,2018)$ survey and synthesize the available data, but conclude that more records are still needed in order to resolve inconsistencies and account for the complexity of spatial and temporal variations.

Recent research initiatives on the southern Cape coast have been directed at addressing this knowledge gap, focusing on sea level, climate and vegetation dynamics during the Holocene (e.g. Haberzettl et al., 2019; Kirsten et al., 2018; Quick et al., 2018; Reinwarth et al., 2013; Strobel et al., 2019; Wündsch et al., 2016a, 2016b, 2018). The climate along the southern Cape coast is influenced by both tropical and temperate climate systems, and the region hosts a highly diverse vegetation including fynbos and thicket elements and includes the Knysna Afrotemperate Region - the most extensive forest complex in southern Africa (Geldenhuys, 1993; Midgley et al., 1997). Studies of the available palaeoenvironmental records have concluded that regional climates have likely been highly 
temperate systems have responded to changing global boundary conditions (Chase et al., 2017; Chase and Quick, 2018), and that these changes have significantly impacted the regional vegetation mosaic (Martin, 1968; Quick et al., 2016, 2018). This apparently highly variable nature of the region's climate and vegetation suggests it is particularly sensitive to climate change, making it an ideal area to evaluate changes in these systems and how they interact over time.

To study vegetation and climate change on the southern Cape coast, we analyzed a 1300year record of fossil pollen and microcharcoal from Bo Langvlei, one of several coastal lakes in the Wilderness Embayment (Figure 1). We present here the first record to come from the region that is sufficiently highly resolved to address questions relating to climate and vegetation change during the last 1000 years (and therefore encompassing the MCA and LIA), and it contributes to the expanding body of work defining a baseline for natural environmental variability along the southern Cape coast.

\section{Regional Setting}

A notable feature of the southern Cape coast is the Wilderness Embayment, which includes a series of lakes separated from the coastline by shore parallel dune ridges of Pleistocene age (Bateman et al., 2011; Illenberger, 1996) (Figure 1). The embayment is underlain by quartzites of the Table Mountain Group as well as Palaeozoic (Ordovician - Silurian) Peninsula Formation sandstones (Bateman et al., 2011; Marker and Holmes, 2002, 2010).

Today the largest of the three lakes of the Wilderness Lakes system, Bo Langvlei $\left(2.14 \mathrm{~km}^{2}\right.$; Watling 1977) is connected by a short channel to Rondevlei to the East, and Eilandvlei to the West. Langvlei Spruit, with a catchment size of $8.2 \mathrm{~km}^{2}$ (Fijen and Kapp, 1995), is the main source of freshwater to Bo Langvlei. Additional contributions are received through occasional overflow from Rondevlei and groundwater from non-lithified sandy sediments that border and underlie parts of the Wilderness Embayment (Fijen and Kapp, 1995).

\section{Climate}


Located in the modern year round, or aseasonal, rainfall zone (YRZ/ARZ) (sensu Chase and Meadows,

101

102

103

104

105

106

107 2007), the contemporary climate of the Wilderness region can be described as temperate oceanic ("Cfb"; Peel et al., 2007) with 800 to $1000 \mathrm{~mm}$ of mean annual rainfall distributed largely uniformly throughout the year (Allanson and Whitfield, 1983; Russel et al., 2012). Winter rainfall along the coast is brought about by frontal depressions embedded in the mid-latitude westerlies, with ridging anticyclones and cut off lows responsible for the majority of the rainfall events (Engelbrecht et al., 2015; Engelbrecht and Landman, 2016; Tyson and Preston-Whyte, 2000). Summer rainfall results from the association of warmer sea surface temperatures in the Indian Ocean and enhanced easterly flow, as well as tropical-temperate trough cloud bands (Engelbrecht et al., 2015; Tyson and PrestonWhyte, 2000). The Agulhas Current also has a major influence on local climatic conditions along the coast, as its warm waters provide a source of moisture, generating increased humidity (Jury et al., 1993).

\section{[Insert Figure 1]}

Figure 1: Panel A Map of southern Africa showing seasonality of rainfall and sharp climatic gradients dictated by the zones of summer/tropical (red) and winter/temperate (blue) rainfall dominance. Major atmospheric (white arrows) and oceanic (blue arrows) circulation systems are indicated. Locations of palaeoenvironmental records discussed in this paper are numbered: 1; Verlorenvlei (Stager et al., 2012), 2; Seweweekspoort (Chase et al., 2013, 2017), 3; Cango Cave (Talma and Vogel, 1992), 4; Groenvlei (Martin 1968; Wündsch et al. 2016a) 5; Bo Langvlei (this paper), 6; Cold Air Cave (Holmgren et al., 1999, 2003; Lee-Thorp et al., 2001; Sundqvist et al., 2013), 7; Pafuri (Woodborne et al., 2015) and 8; Lake Sibaya (Neumann et al., 2008; Stager et al., 2013). Panel B Aridity index map of the southwestern Cape (black box in A). Locations of palaeoenvironmental records are numbered as in Panel A. Panel C The Wilderness lakes region, indicating the location of Bo Langvlei and the current distribution of dominant vegetation types (Mucina and Rutherford, 2006). 
126 Vegetation in the Wilderness region consists of a mosaic of fynbos and thicket elements with pockets of Knysna Afrotemperate forest also present (Cowling and Heijinis, 2001). In the immediate vicinity of the lakes, including the interconnecting channels, semi-aquatic vegetation is represented by bulrushes (Typha latifolia), reeds (Phragmites australis) and sedges (Scirpus littoralis) (Allanson and Whitfield, 1983; Russel et al., 2012). The area inundated during extremely high water levels represents an intermediate zone between the semi-aquatic and terrestrial environments and is occupied by rushes such as Juncus kraussi (Allanson and Whitfield, 1983; Russel et al., 2012). Azonal vegetation specifically along the estuaries is represented by halophytic taxa with Sarcocornia capensis and S. pillansii (Amaranthaceae), Chenolea diffusa (Amaranthaceae) and Plantago

\section{Material and Methods}


151 Coring was undertaken at Bo Langvlei during October 2013 as part of the first fieldwork campaign for

152

153

154

155

156

157

158

159

160

161

162

163

164

165

166

167

168

169

170

171

172

173

174

175

176

the RAiN project (Haberzettl et al., 2014). The core, BoLa $13.2\left(33^{\circ} 59^{\prime} 12.54^{\prime \prime}\right.$ S, $\left.22^{\circ} 40^{\prime} 44.46^{\prime \prime} \mathrm{E}\right)$, was retrieved using a modified ETH-gravity corer (Kelts et al., 1986), and measures $178.5 \mathrm{~cm}$ in length. BoLa 13.2 was opened at the Institute of Geography at Friedrich Schiller University Jena, Germany where it was photographed, lithologically described and sampled. The core was continuously subsampled in a closed laboratory setting at a resolution of $1 \mathrm{~cm}$ for both pollen and microcharcoal analysis.

\section{Chronology}

The BoLa 13.2 age-depth model was established using both ${ }^{210} \mathrm{~Pb}$ and ${ }^{14} \mathrm{C}$ ages. 24 bulk samples from the top $12 \mathrm{~cm}$ of the core (at $0.5 \mathrm{~cm}$ intervals) were sent to the Radiochronology Laboratory (Centre for Northern Studies, Laval University, Quebec, Canada) for ${ }^{210} \mathrm{~Pb}$-dating. For AMS- ${ }^{14} \mathrm{C}$ dating, five organic sediment samples were sent to Beta Analytic Inc. (Miami, Florida, USA). The ${ }^{14} \mathrm{C}$ age for the sample at $45.5 \mathrm{~cm}$ was calibrated using the SHcal13 curve (Hogg et al., 2013) as the radiocarbon content of the uppermost sample showed 105.5 $\pm 0.3 \mathrm{pMC}$ indicating the absence of a reservoir effect in the lacustrine facies of the sediment. The Marine13 data set (Reimer et al., 2013) was applied for the samples at $98.5 \mathrm{~cm}, 137.5 \mathrm{~cm}$ and $178.5 \mathrm{~cm}$, respectively as the lithology indicated that sediment in these depths is of marine origin. A marine reservoir correction of $\Delta R=148 \pm 27$ was applied here in reference to recent studies by Wündsch et al. (2016a) and Haberzettl et al. (2019). The CRS (constant rate of ${ }^{210} \mathrm{~Pb}$ supply) model (Appleby, 2008; Appleby and Oldfield, 1978) was applied to the ${ }^{210} \mathrm{~Pb}$ results to obtain the ages. The age-depth model was subsequently developed using the R software package Bacon (v2.2) (Blaauw and Christen, 2011).

\section{[Insert Table 1]}

Table 1: Radiocarbon ages and calibration details. Ages are presented as both cal BP and AD where relevant.

\section{[Insert Table 2]}




\section{[Insert Figure 2]}

Figure 2: The BoLa 13.2 lithology and age-depth model. The age-depth model was developed using the R software package Bacon (V2.2) (Blaauw and Christen 2011). The $2 \sigma$ probability distribution of calibrated ${ }^{14} \mathrm{C}$ ages is presented in blue and the $95 \%$ confidence intervals are represented by the grey dotted line. ${ }^{210} \mathrm{~Pb}$ ages are represented by the turquoise area and the red line represents the best model according to the weighted mean age at each depth. BoLa 13.2 is divided into four lithological units. Unit I $(178-100 \mathrm{~cm})$ predominantly consists of silty sand and is characterized by an abundance of marine shell fragments. A gradual coarsening of sediment is observed in Unit II-a (100 - $94 \mathrm{~cm})$, changing to finer silty clay in Unit II-b $(94-86 \mathrm{~cm})$. Marine shell fragments appear less frequently upwards of $94 \mathrm{~cm}$. Unit III $(86-27 \mathrm{~cm})$ is mainly composed of clayey silt. Units IV $(27-6 \mathrm{~cm})$ and V $(6-0 \mathrm{~cm})$ consists of the similar fine-grained sediment as Unit III. Unit IV is characterized by the presence of filamentous plant material, while marine shell fragments are present again in Unit V.

\section{Pollen and microcharcoal analysis}

In total, 84 samples were processed for pollen and microscopic charcoal analyses. Samples from the basal $78.5 \mathrm{~cm}$ of the core yielded insufficient pollen concentrations for analysis. Standard palynological methods were employed as per Faegri \& Iversen (1989) and Moore et al. (1991) with particular adaptations for dense media separation (Nakagawa et al., 1998) in order to extract palynomorphs. These adaptations included the removal of carbonates and humic acids using $30 \%$ $\mathrm{HCl}$ and $10 \% \mathrm{KOH}$, respectively. This was followed by heavy liquid separation, through the use of $\mathrm{ZnCl}_{2}$, in order to separate pollen grains from the non-pollen matrix (Faegri and Iversen, 1989; Moore et al., 1991; Nakagawa et al., 1998). Acetolysis was further applied to remove any cellulose and/or organic matter still present in the sample, after which the samples were mounted on slides using the aqueous mounting agent Aquatex. Three slides were produced per sample and $0.5 \mathrm{ml}$ of 
LacCore's polystaene microsphere pollen spike was added to each sample to determine pollen concentrations and absolute counts.

Plus microscope with magnifications from $400 x$ to $1000 x$. Three samples exhibited lower pollen concentrations, and from these only 222 (AD 1965), 280 (AD 740) and 299 (AD 760) grains were

Geographical Science department at the University of Cape Town was used, as was reference material from Van Zinderen Bakker (1953, 1976), Van Zinderen Bakker and Coetzee (1959), Welman and Kuhn, (1970) and Scott (1982). The counting process was aided by the use of the software program Polycounter, version 2.5.3 (Nakagawa, 2007). Charcoal particles were counted in conjunction with pollen grains. Particle number was recorded according to the guidelines of Tinner \& Hu (2003) with only black, opaque and angular fragments $>75 \mu \mathrm{m}^{2}$, or $\sim 10 \mu \mathrm{m}$ in length, being counted. These fragments were classified into two groups according to size: $10-100 \mu \mathrm{m}$ and $>100 \mu \mathrm{m}$ (Tinner and $\mathrm{Hu}, 2003)$. Charcoal concentrations were calculated using the microsphere spike, as with the pollen concentrations. package Tilia (version 1.7.16) (Grimm, 2011). Zonation of the diagrams was achieved using the

CONISS (Constrained Incremental Sum of Squares) module of the same software using stratigraphically constrained analysis and square root transformation of the data (Grimm, 1987).

\section{TraCE21ka climate model}

To compare our results with general circulation model simulations, we use data from the TraCE21ka experiment (He et al., 2013; Liu et al., 2009; Otto-Bliesner et al., 2014). TraCE21ka used the Community Climate System Model ver. 3; (Collins, 2006) a global coupled atmosphere - ocean - sea ice - land general circulation model that has a latitude - longitude resolution of $\sim 3.75^{\circ}$ in the atmosphere and $\sim 3^{\circ}$ in the ocean and includes a dynamic global vegetation module. The simulation includes transient orbitally forced insolation changes and changes in the atmospheric concentrations 
of carbon dioxide, methane and nitrous oxide, as well as the evolution of ice sheets and their meltwater contributions to the ocean. The climate data have been regridded using bilinear interpolation to a spatial resolution of $2.5^{\circ} \times 2.5^{\circ}$ (latitude/longitude) (Fordham et al., 2017).

\section{Results}

\section{Chronology}

234 The ${ }^{14} \mathrm{C}$ ages (Table 1 ) indicate that BoLa13.2 has a basal age of $4140+185 /-220$ cal BP (Figure 3). 235 The results from the CRS-model of ${ }^{210} \mathrm{~Pb}$ activity (Table 2) provide ages for the top $12 \mathrm{~cm}$ of the core 236 ranging from AD 1825 to present. The age-depth model suggests continuous deposition and an 237 average sedimentation rate of $0.07 \mathrm{~cm} \mathrm{y}^{-1}$.

\section{$238 \quad$ Pollen and microcharcoal analyses}

Due to the sandy nature of the sediment in Unit I, as well as the presence of marine shells, it was inferred that this unit represents marine conditions within the lake. Accordingly, it is suggested that this marine environment was not conducive to the preservation of organic matter hence the inadequate pollen preservation below $100 \mathrm{~cm}$. As such, the pollen record encompasses the time period from $A D 680+530 /-110$ to present.

The BoLa13.2 pollen assemblage are summarized by ecological affinity based on the primary vegetation types present in the region today, of which the main contributor is the fynbos vegetation group, with Ericaceae, Restionaceae and Stoebe-type pollen being most prevalent. Succulent and/or drought resistant taxa are mainly represented by Euphorbia with lesser contributions from Aizoaceae and Crassula, while Olea is the main constituent of the coastal thicket group. Podocarpus dominates the Afrotemperate forest group with the other taxa in this group making negligible contributions. Cyperaceae, Juncaceae and Typha were deemed to form part of the local wetland taxa, and Amaranthaceae is also included in this group as it is an indicator of salt marsh conditions. These local wetland taxa were excluded from the total pollen sum. From the cluster analysis results, 
the pollen and charcoal diagrams were divided into six pollen assemblage zones - BoLa13.2-A to BoLa13.2-F. Zone BoLa13.2-A represents the oldest part of the pollen sequence, c. AD 650 to 750. As for much of the record, fynbos taxa dominate this zone, exhibiting increasing percentages towards the top of the zone, with a concomitant peak in the charcoal concentration. Relative to mean values for the whole of the record, succulent/drought resistant taxa are more prevalent in this zone, most notably Euphorbia. Coastal thicket is present throughout this period, since taxa from this group are relatively abundant. Afrotemperate forest (predominantly Podocarpus) pollen is relatively low during this period. zone BoLa13.2-B (c. AD 750 to 1000). A prominent increase in coastal thicket (Olea, Euclea and Celastraceae) is noted $\sim A D 820$ after which values remain consistently elevated throughout the rest of the zone. Afrotemperate forest pollen is notably more abundant during this period. There is, however, a sharp decline AD 900, a point where the fynbos elements Ericaceae and Passerina reach maximum percentages. Additionally, (non-local) aquatic vegetation is completely absent, while the pollen concentration is at a minimum $\left(1.4 \times 10^{3}\right.$ grains $\left.\mathrm{g}^{-1}\right)$. Towards the end of the zone, a marked peak in charcoal concentration is evident $\sim A D 980$ along with slightly elevated values noted for fynbos (mostly Stoebe-type) and Euphorbia.

BoLa13.2-C (c. AD 1000 to 1100 ) is the shortest of the pollen assemblage zones, including only three samples. Podocarpus is present at a minimum AD 1000, with Icacinaceae the only other forest element present here. Simultaneously, Ericaceae representation is notably elevated (17\%) and Cyperaceae, representing local wetland vegetation, occurs minimally. At the top of the zone previous zones with succulent/drought resistant taxa remain present at higher levels throughout the zone. 

by the halophytic element Amaranthaceae which achieves maximum values AD 1150. The fynbos taxa Passerina and Stoebe-type exhibit relatively high percentages at the beginning of the period, and then decline between $\sim A D 1230$ and $A D$ 1410. The inverse of this pattern is observed in Podocarpus, which increases from the beginning of the period, and maintains high levels until $\sim A D$ 1550. Succulent/drought resistant taxa remain generally constant throughout the zone. Towards the top of the zone, $\sim A D 1550$, both pollen- $\left(13.89 \times 10^{3}\right.$ grains $\left.\mathrm{g}^{-1}\right)$ and charcoal $\left(5.27 \times 10^{4}\right.$ fragments $\mathrm{g}^{-}$ $\left.{ }^{1}\right)$ concentrations are at their highest.

The beginning of zone BoLa13.2-E (c. AD 1600 to 1900) is marked by a sharp decline in both Amaranthaceae and Podocarpus, and an increase in fynbos taxa, particularly Stoebe-type. This latter remains abundant throughout the zone, reaching maximum representation $\sim A D 1800$. Charcoal concentrations are close to their lowest values at this point. Pinaceae also appears for the first time towards the top of the zone, AD 1850. Podocarpus percentages are variable but notably lower than in zone BoLa13.2-D. Succulent/drought resistant taxa show a similar, but subtler pattern, declining after $\sim A D 1750$ towards the top of the zone.

Zone BoLa13.2-F represents the top of the core, extending from AD 1900 to the top of the record. Fynbos generally declines across this zone apart from a peak between AD 1950 and 1980 . percentages increasing until AD 1960, after which both decline. Podocarpus continues to exhibit an inverse relationship to Stoebe-type pollen during this period, with a peak AD 1920, a sharp decline AD 1960, followed by a period of increasing values until AD 1990, when it reaches its highest levels. Charcoal concentrations are at their lowest for the whole assemblage at this point.

\section{[Insert Figure 3]}

Figure 3: Relative pollen percentage diagram for BoLa13.2 organized according to ecological affinity. Pollen 

CONISS.

\section{[Insert Figure 4]}

Figure 4: Charcoal and pollen concentrations for BoLa13.2. Only charcoal fragments smaller than $100 \mu \mathrm{m}$ were present. Charcoal and pollen concentrations were calculated in the same manner using microsphere counts.

The zonation of the diagram is the same as for the pollen diagram.

\section{Discussion}

\section{Climate and environmental change during the last 1300 years at Bo Langvlei}

Despite the diversity of vegetation types present in the Wilderness Embayment region, and observed in the Bo Langvlei record, there are several primary patterns in the fossil record that can be used to infer past environmental changes. Foremost among these is the variability observed in the 1) Afrotemperate forest pollen record (dominated by Podocarpus) and 2) Stoebe-type pollen, which is one of the most prevalent fynbos taxa. Afrotemperate forests, and Podocarpus in particular, are sensitive to drought, and in the fossil record related pollen types have been shown to be valuable indicators of aridity/humidity in the region (e.g. Quick et al. 2018) (with aridity/humidity being distinct from rainfall amount per se [see Chevalier \& Chase 2016]). Stoebe-type pollen is most clearly associated with cooler temperatures, making it an important indicator of past temperature change at many sites in South Africa (Quick et al., 2016; Scott, 1982; Scott et al., 2012). Considering these elements of the pollen record, it is possible to infer general changes in - and relationships between - moisture and temperature at Bo Langvlei.

In this paper, we limit the contextualization of these results to records within the southern

327 Cape, and select keystone records from more distant regions that can be used to infer mechanistic relationships with southern Cape climates. This selection was made on the basis of a record's resolution, age control, and the extent to which the proxy can be reasonably interpreted in terms of changes in temperature and/or hydroclimate. Other records spanning the last 1300 years do exist in 
southern Africa (e.g. Norström et al., 2018; Scott, 1996; Stager et al., 2013), but we defer detailed inter-regional consideration of these records for a fuller synthetic study.

\section{[Insert Figure 5]}

Figure 5: Comparison of Northern Hemisphere temperature reconstruction (Moberg et al., 2005) with percentages of Stoebe-type (cold indicator) and Afrotemperate forest (humidity indicator) pollen and key palaeoclimate records southern Africa (location of sites indicated in Figure 1). The Medieval Climate Anomaly (MCA) and Little Ice Age (LIA) are indicated by red and blue shading, respectively, with the degree of shading within these periods indicating the strength of the reconstructed Northern Hemisphere temperature anomaly (Moberg et al., 2005) relative to the average temperatures between AD 500 and 1979.

From c. AD 650 to 900 the landscape around Bo Langvlei was generally characterized by open scrub vegetation, dominated by ericoid/restioid fynbos (Figure 4). Despite the prevalence of fynbos vegetation, relatively low levels of Stoebe-type and Passerina pollen imply that conditions were not significantly cooler than present. Levels of Afrotemperate forest pollen are low during this period, while succulent/drought-resistant taxa and coastal thicket vegetation is relatively abundant, indicating drier conditions and a diverse mosaic of vegetation in the Wilderness Embayment during this period. (MCA; AD 950 - 1250, Jones et al. 2001) - begins with a peak in Afrotemperate forest pollen from c. $A D 900$ to $A D$ 950, followed by a decline to minimum values AD 980, indicating dry conditions, and a subsequent progressive increase until AD 1300 (Figure 4, 5). At Groenvlei, $20 \mathrm{~km}$ to the east of Bo Langvlei in the Wilderness Embayment, changes in terrigenous sediment fluxes (e.g., grain size percentages, $\mathrm{Ti}$ and $\mathrm{Fe}$ counts) have been interpreted as - in part - indicators of rainfall amount/intensity (Wündsch et al. 2016a). These records show similar patterns to the Bo Langvlei Afrotemperate forest pollen record at multi-centennial timescales (Figure 5) and indicate that the 
the strongly variable nature of Amaranthaceae pollen frequencies. Quick et al. (2018), noted that in this setting Amaranthaceae most likely represents halophytic species like Salicornia (Slenzka et al., 2013); however, the presence of Amaranthaceae could also be related to drier and more evaporative conditions. The strong negative correlation between Amaranthaceae and Afrotemperate forest taxa during this period suggests that it may have been a time of greater climatic variability and lower moisture availability.

In terms of temperature, Stoebe-type pollen is present at minimum values from c. AD 900 to AD 950, increases slightly until AD 1180, and then declines as Afrotemperate forest pollen increases in abundance. This potential indication of slightly cooler conditions around this time runs counter to some other studies (Lüning et al., 2017; Tyson et al., 2000; Tyson and Lindesay, 1992), but the existing evidence from southern Africa does not unequivocally indicate warmer conditions during the MCA (see Nicholson et al. 2013; Figure 5). The Cango Cave speleothem palaeotemperature record - the closest temperature record to Bo Langvlei - indicates only a slight warming during the MCA, while the Cold Air Cave speleothem records indicate cooler conditions (Holmgren et al., 2003; Lee-Thorp et al., 2001) according to the $\delta^{18} \mathrm{O}$ interpretation of Sundqvist et al. (2013) (lower values indicating cooler conditions). When considered with the $\delta^{13} \mathrm{C}$ (lower values indicating less shallowrooting grass and thus drier conditions) and grey-scale records from Cold Air Cave (Holmgren et al., 2003; Lee-Thorp et al., 2001), this cooling may be associated with weakened tropical influence in eastern South Africa and the southern Cape. Concurrent indications of increased precipitation at Verlorenvlei in the Western Cape (Stager et al., 2012) and more humid conditions at nearby Seweweekspoort (Chase et al., 2013, 2017) may suggest the increased influence of temperate circulation systems at this time, supporting the model of an coeval inverse relationship between temperate and tropical circulation systems in South Africa (Cockroft et al., 1987; Van Zinderen Bakker, 1976). While simulations of seasonal precipitation in the Bo Langvlei region are complex during the MCA, precipitation seasonality is generally higher (Figure 6) (He et al., 2013; Liu et al., 
2009). This is consistent with a decrease in Afrotemperate forest pollen, which favours regular rainfall and low seasonality.

\section{[Insert Figure 7]}

Figure 7: Comparison of Northern Hemisphere temperature reconstruction (Moberg et al., 2005) with percentages of Stoebe-type (cold indicator) and Afrotemperate forest (humidity indicator) pollen and climatic parameters for the Wilderness region obtained from the TraCE-21k transient climate model simulation (He et al., 2013; Liu et al., 2009). The Medieval Climate Anomaly (MCA) and Little Ice Age (LIA) are indicated by red and blue shading, respectively, with the degree of shading within these periods indicating the strength of the reconstructed Northern Hemisphere temperature anomaly (Moberg et al., 2005) relative to the average temperatures between $A D 500$ and 1979.

when interpreting the Bo Langvlei record. Major peaks in charcoal concentration are observed at AD $715+500 /-130$, AD $980+330 /-180$, AD $1265+150 / \_95$ and $A D 1550+140 /-160$, indicative of discrete periods of increased fire activity and/or large fire events. These episodes are often followed by declines in forest pollen and increases in fynbos representation (Figure 5), which might be expected considering the fire-adapted nature of fynbos (Cowling et al., 2004). Afrotemperate forest percentages and charcoal concentrations exhibit a generally positive relationship for these major peaks, which may appear contradictory, as fires are associated with more seasonal rainfall or drier conditions. In absence of other charcoal records that may help elucidate the regional significance of these data, we propose that the relationship with forest pollen may relate to increases in biomass, which would result in a larger charcoal flux, and/or the warmer conditions that appear to foster forest expansion. Under warmer conditions, periods of increased seasonality or anomalously dry years or decades may occur that provide favorable conditions for ignition, and the accumulation of forest biomass may result in larger fires. Moreover, the occurrence of periodically more extreme 
berg wind conditions can have a desiccating effect on vegetation, increasing the flammability of habitually moist vegetation, such as forests (Geldenhuys, 1994). A more detailed study of long-term fire ecology in the Wilderness region and Afrotemperate Forest Biome is clearly warranted. In general, the palaeoenvironmental data described above appear to support climatic factors as being the primary determinant of the Bo Langvlei pollen record. However, as declines in Afrotemperate forest pollen systematically follow the major charcoal peaks in the record, the sensitivity of this vegetation type to fire, and its recovery time follow major burning events/phases may also influence the record, perhaps amplifying declines in Afrotemperate forest pollen at the beginning of more arid phases and contributing to the pattern of progressive increases in this pollen type during these periods.

Towards the end of the MCA interval the landscape appears to have become progressively more forested, as Afrotemperate forest percentages increase significantly after AD 1200. Although of lower resolution, a similar expansion of forest is noted in the Groenvlei (Martin, 1968) and Eilandvlei (Quick et al., 2018) pollen records, with wetter than present conditions inferred for the region from c. AD 1250 to 1350 (Wündsch et al. 2016a). The Bo Langvlei record indicates that the period from c. AD 1200 to 1400 , spanning the transition from the MCA to the LIA is characterized by relatively warm (low levels of Stoebe-type pollen) and humid (increased Afrotemperate forest pollen) conditions (Figure 5). These findings are supported by the palaeotemperature records from Cango Cave (Talma and Vogel, 1992) and Cold Air Cave (Holmgren et al., 2003; Lee-Thorp et al., 2001), records of terrestrial sediment flux at nearby Groenvlei (Wündsch et al. 2016a), and reductions in simulated precipitation seasonality (He et al., 2013; Liu et al., 2009). After AD 1400, broadly coincident with the onset of Northern Hemisphere Little Ice Age cooling, percentages of Stoebe-type pollen begin to increase significantly, indicating cooling in the Wilderness Embayment region (Figure 5). This cooling coincides with a period of forest retreat and drier conditions (declining Afrotemperate forest percentages and reduced terrestrial sediment flux at Groenvlei (Wündsch et al. 2016a)), with the period from c. AD 1400 to 1600 exhibiting marked 
environmental variability, with strong shifts between warm-wet and cool-dry conditions. The Cold

Air Cave speleothem records indicate a cooling and drying trend in the northern summer rainfall zone at this time (Holmgren et al., 2003; Lee-Thorp et al., 2001), while the lower resolution Cango Cave speleothem records a strong increase in temperature (Talma and Vogel, 1992). The Verlorenvlei diatom record has been interpreted as indicating increased - but variable precipitation in the winter rainfall zone (Stager et al., 2012). Based on simulations of winter rainfall amount in the region, these findings cannot be easily extrapolated to the Wilderness Embayment, but patterns in simulated rainfall seasonality are consistent with expectations based on Afrotemperate forest pollen (Figure 6). The challenges in determining the influence of tropical versus temperate circulation systems on winter and summer rainfall regimes in the southern Cape has become increasingly recognized in recent years (Chase et al., 2017, 2020; Chase and Quick, 2018), and further data from both terrestrial and marine archives is required to adequately address these questions.

From around c. AD 1600 to 1850 - the coldest portion of the LIA (Matthews \& Briffa 2005) fynbos elements dominate the landscape, most notably Stoebe-type and the cryophilic element Passerina, clearly indicating cooler conditions at Bo Langvlei at this time. A strong decline in Afrotemperate forest pollen is also observed, signaling substantially drier conditions (Figure 5). This is further supported by increased Asteraceae pollen, suggestive of drier, more asteraceous fynbos. These findings are consistent with Cango Cave palaeotemperature reconstructions (Talma and Vogel, 1992) and inferences of drier conditions at Groenvlei (Wündsch et al. 2016a). The Cold Air Cave record also indicates cool, dry conditions in the northern summer rainfall zone during this period (Holmgren et al., 2003; Lee-Thorp et al., 2001), as does the Parfuri baobab tree-ring record 457 (Woodborne et al., 2015). In contrast, the Seweweekspoort (Chase et al., 2013, 2017) and 458 Verlorenvlei (Stager et al., 2012) records suggest increased temperate influence/winter rain, 459 respectively. Considering the opposing trends between Verlorenvlei and Bo Langvlei, it can be hypothesised that the influence of the frontal systems associated with the westerly storm-track was 
not sufficient along the southern Cape coast to compensate for the concurrent reduction in tropical/local rainfall in the region.

After AD 1850, fynbos pollen - and Stoebe-type pollen in particular - decreases sharply,

and there are marked increases in Podocarpus pollen, consistent with warmer, more humid conditions at Groenvlei (Wündsch et al. 2016a). It seems that the LIA was followed by a period of increasing temperatures and moisture availability and the establishment of the current aseasonal rainfall pattern in the Wilderness area. This trend is also observed at Eilandvlei (Quick et al., 2018) and Cango Cave (Talma and Vogel, 1992), and thus seems to be a well-defined response in at least this portion of the southern Cape. It should be noted that this period is one of increasing colonial human impact in the region, with Pinus appearing in the Bo Langvlei record from AD 1850. As Stoebe-type pollen has in some cases been related to disturbance (Meadows et al., 1996) it may be that some of the variability observed in the most recent portion of the record may be related to nonclimatic influences.

\section{Conclusions}

The Bo Langvlei pollen record provides valuable information regarding past temperature, moisture and vegetation change from the southern Cape Coast during the past 1300 years. Consideration of this period is often framed in terms of the Medieval Climate Anomaly (MCA; C. AD $950-1250$ ) and the Little Ice Age (LIA; C. AD 1300 - 1850) (Jones et al. 2001; Matthews \& Briffa 2005; PAGES2k 2013), which have largely been defined based on evidence from the Northern Hemisphere. Syntheses of palaeoenvironmental records from southern Africa have sometimes concluded that regional patterns have been coherent with these periods of warmer and cooler climates (e.g. Lüning et al., 2017; Tyson et al., 2000; Tyson and Lindesay, 1992), but other works have highlighted a more complex spatio-temporal patterning of climate anomalies (e.g., Nicholson et al. 2013; Nash et al. 2016).

The data presented in this paper - together with other records from the Wilderness 
and perhaps slightly cooler than present. The most durable phase of forest expansion, and likely more humid conditions, occurred during the transition between the MCA and core cooling of the LIA. Data from the TraCE-21ka transient simulation (He et al., 2013; Liu et al., 2009) indicate that this was a period of reduced rainfall seasonality, which would be consistent with the expansion of drought-sensitive forest taxa like Podocarpus. The strongest signal preserved in the Bo Langvlei pollen record is the period of cool, dry conditions that occurred during the LIA, most notably from c. AD 1600 to 1850 . Post-LIA warming occurred rapidly after AD 1850, but some of the subsequent variability observed may be related to non-climatic factors such as intensifying colonial land use. generally linked to changes in temperature, and changes in the influence of tropical systems, perhaps transmitted at least in part via the Agulhas Current and the development of localized precipitation systems (cf. Chase and Quick, 2018). During relatively warmer periods, moisture availability was apparently higher, and rainfall was perhaps less seasonal, fostering the development and expansion of Afrotemperate forests. During colder periods, precipitation resulting from tropical disturbances or relating to higher Agulhas Current sea-surface temperatures was more restricted, resulting in drier conditions, and possibly greater seasonal contrasts in rainfall. Records from Seweweekspoort (Chase et al., 2013, 2017) and Verlorenvlei (Stager et al., 2012), which have been associated with temperate circulation system controls, indicate wetter conditions during the LIA. This supports to a degree the commonly cited coeval inverse relationship between tropical and temperate moisture-bearing systems, and increased westerly influence under globally cooler conditions (see Chase and Meadows, 2007; Tyson, 1999; Van Zinderen Bakker, 1976). The limited coast, as suggested by Quick et al. (2018). 
with trends in Afrotemperate forest pollen. However, the drying trend during the LIA is simulated as resulting from a decline in winter rainfall, in apparent contradiction with the above-mentioned inferences and conceptual models. Whether this is due to insensitivity or inaccuracy in the models at these spatio-temporal scales during the late Holocene, or the need for refinement of interpretive paradigms, as has been recently suggested (e.g., Chase et al. 2017; Chase \& Quick 2018) remains unclear. More data along transects encompassing the climate gradients of the southern Cape region are required to develop a more comprehensive understanding of regional climate dynamics, drivers and the impact of climate change on regional environments.

\section{Acknowledgements}

This study was funded by the German Federal Ministry of Education and Research (BMBF). The investigations were conducted within the collaborative project 'Regional Archives for Integrated Investigations' (RAiN), which is embedded in the international research program SPACES (Science and Vivienne Jones for their constructive comments.

\section{References}

Allanson BR and Whitfield AK (1983) The Limnology of the Touw River Floodplain. Port Elizabeth.

Appleby PG (2008) Three decades of dating recent sediments by fallout radionuclides: a review. The Holocene 18(1). Sage PublicationsSage UK: London, England: 83-93. DOI: 10.1177/0959683607085598.

Appleby PG and Oldfield F (1978) The calculation of lead-210 dates assuming a constant rate of supply of unsupported 210Pb to the sediment. CATENA 5(1). Elsevier: 1-8. DOI: 10.1016/S0341-8162(78)80002-2. Ltd: 63-81. DOI: 10.1016/j.quascirev.2010.10.003. 

process. Bayesian Analysis 6(3). International Society for Bayesian Analysis: 457-474. DOI: 10.1214/11BA618.

Chase B, Chevalier M, Boom A, et al. (2017) The dynamic relationship between temperate and tropical circulation systems across South Africa since the last glacial maximum. Quaternary Science Reviews 174:

Chase BM and Meadows ME (2007) Late Quaternary dynamics of southern Africa's winter rainfall zone. EarthScience Reviews 84(3-4): 103-138. DOI: 10.1016/j.earscirev.2007.06.002.

Chase BM and Quick LJ (2018) Influence of Agulhas forcing of Holocene climate change in South Africa's southern Cape. Quaternary Research (United States) 90(2): 303-309. DOI: 10.1017/qua.2018.57.

Chase BM, Boom A, Carr AS, et al. (2013) Holocene climate change in southernmost South Africa : rock hyrax DOI: 10.1016/j.quascirev.2013.10.018.

Chase BM, Boom A, Carr AS, et al. (2020) High-resolution record of Holocene climate change dynamics from southern Africa's temperate-tropical boundary, Baviaanskloof, South Africa. Palaeogeography,

Chevalier M and Chase BM (2016) Determining the drivers of long-term aridity variability: A southern African case study. Journal of Quaternary Science 31(2): 143-151. DOI: 10.1002/jqs.2850.

Cockroft MJ, Wilkinson MJ and Tyson PD (1987) The application of a present-day climate model to the late Quaternary in southern Africa. Climatic Change 10: 161-181. systematic conservation planning in the Cape Floristic Region. South African Journal of Botany 67: 15-38. 
Engelbrecht CJ, Landman WA, Engelbrecht FA, et al. (2015) A synoptic decomposition of rainfall over the Cape south coast of South Africa. Climate Dynamics 44(9-10): 2589-2607. DOI: 10.1007/s00382-014-2230-5. Faegri K and Iversen J (1989) Textbook of Pollen Analysis. Chichester: John Wiley \& Sons Ltd.

Fijen APM and Kapp JF (1995) Wilderness Lakes catchment, Touw and Duiwe Rivers, water management strategy. Volume 1: Present situation. Pretoria: Department of Water Affairs and Forestry.

Fordham DA, Saltré F, Haythorne S, et al. (2017) PaleoView: a tool for generating continuous climate projections spanning the last 21000 years at regional and global scales. Ecography 40: 1348-1358.

Geldenhuys CJ (1993) Floristic composition of the southern Cape forests with an annotated check-list. South African Journal of Botany 59(1): 26-44.

Geldenhuys CJ (1994) Bergwind fires and the location pattern of forest patches in the southern Cape landscape , South Africa. Journal of Biogeography 21(1): 49-62.

Grimm EC (1987) CONISS: A Fortran 77 program for stratigraphically constrained cluster analysis by the method of incremental sum of squares. Computers \& Geosciences 13: 13-35.

Grimm EC (2011) Tilia 1.7.16.

Haberzettl T, Baade J, Compton J, et al. (2014) Paleoenvironmental investigations using a combination of terrestrial and marine sediments from South Africa - The RAIN (Regional Archives for Integrated iNvestigations) approach. Zentralblatt für Geologie und Paläontologie, Teil / 2014(1): 55-73. DOI: 10.1127/zgpi/2014/0055-0073.

Haberzettl T, Kirsten KL, Kasper T, et al. (2019) Using ${ }^{210} \mathrm{~Pb}$-data and paleomagnetic secular variations to date anthropogenic impact on a lake system in the Western Cape, South Africa. Quaternary Geochronology 51(January). Elsevier: 53-63. DOI: 10.1016/j.quageo.2018.12.004.

He F, Shakun J, PU C, et al. (2013) Northern Hemisphere forcing of Southern Hemisphere climate during the last deglaciation. Nature 494: 81-85.

Hogg AG, Hua Q, Blackwell PG, et al. (2013) SHCal13 Southern Hemisphere Calibration, 0-50 000 Years Cal BP. Radiocarbon 55(4): 1889-1903.

Holmgren K, Karlen W, Lauritzen SE, et al. (1999) A 3000-year high-resolution stalagmite- based record of palaeoclimate for northeastern South Africa. The Holocene 9(3): 295-309.

Holmgren K, Lee-Thorp JA, Cooper GRJ, et al. (2003) Persistent millennial-scale climatic variability over the past 25,000 years in Southern Africa. Quaternary Science Reviews 22(21-22): 2311-2326. DOI: 
Illenberger WK (1996) The Geomorphological Evolution of the Wilderness Dune Cordons, South Africa. Quaternary International 33: 11-20.

Jones PD, Osborn TJ and Briffa KR (2001) The evolution of climate over the last millennium. Science 292(5517):

602 $662-667$.

Jury MR, Valentine HR and Lutjeharms JRE (1993) Influence of the Agulhas Current on Summer Rainfall along the Southeast Coast of South Africa. Journal of Applied Meteorology 32: 1282-1287.

Kelts K, Briegel U, Ghilardi K, et al. (1986) The limnogeology-ETH coring system. Swiss Journal of Hydrology 48(1). Birkhäuser-Verlag: 104-115. DOI: 10.1007/BF02544119.

Kirsten KL, Haberzettl T, Wündsch M, et al. (2018) A multiproxy study of the ocean-atmospheric forcing and the impact of sea-level changes on the southern Cape coast, South Africa during the Holocene.

Lee-Thorp JA, Holmgren K, Lauritzen SE, et al. (2001) Rapid climate shifts in the southern African interior throughout the mid to late Holocene. Geophysical Research Letters 28(23): 4507-4510.

Liu Z, Otto-Bliesner B, He F, et al. (2009) Transient simulation of last deglaciation with a new mechanism for Bølling-Allerød warming. Science 325: 310-314.

Lüning S, Galka M and Vahrenholt F (2017) Warming and Cooling: The Medieval Climate Anomaly in Africa and Arabia. Paleooceanography 32: 1219-1235. DOI: 10.1002/2017PA003237.

Lüning S, Ga M, Danladi IB, et al. (2018) Hydroclimate in Africa during the Medieval Climate Anomaly. Palaeogeography, Palaeoclimatology, Palaeoecology 495(January): 309-322. DOI: 10.1016/j.palaeo.2018.01.025.

Marker ME and Holmes PJ (2002) The distribution and environmental implications of coversand deposits in the Southern Cape, South Africa. South African Journal of Geology 105: 135-146.

Marker ME and Holmes PJ (2010) The geomorphology of the Coastal Platform in the southern Cape. South African Geographical Journal 92(2): 105-116. DOI: 10.1080/03736245.2010.522041. and Palynology 7: 107-144. 
Meadows ME, Baxter AJ and Parkington J (1996) Late Holocene Environments at Verlorenvlei, Western Cape Province, South Africa. Quaternary International 33: 81-95.

Midgley JJ, Cowling RM and Seydack A (1997) Forest. In: Cowling RM, Richardson DM, and Pierce SM (eds) Vegetation of Southern Africa. Cambridge: Cambridge University Press, pp. 278-299. (eds) Vegetation of Southern Africa. Cambridge: Cambridge University Press, Cambridge, UK, pp. 278296.

Moberg A, Sonechkin DM, Holmgren K, et al. (2005) Highly variable Northern Hemisphere temperatures reconstructed from low- and high-resolution proxy data. Nature 433(10 February): 613-618. DOI: 10.1038/nature03298.1.

Moore PD, Webb JA and Collinson ME (1991) Pollen Analysis. 2nd ed. Oxford: Blackwell Scientific Publications. African National Biodiveristy Institute, Sterlitzia.

Nakagawa T (2007) PolyCounter ver.1.0 \& Ergodex DX-1: a cheap and very ergonomic counter board system. Quaternary International 167-668(Supplement): 3-486.

Nakagawa T, Brugiapaglia E, Digerfeldt G, et al. (1998) Dense media separation as a more efficient pollen extraction method for use with organic sediment/deposit samples: comparison with the conventional method. Boreas 27: 15-24.

Neukom R, Steiger N, Gómez-Navarro JJ, et al. (2019) No evidence for globally coherent warm and cold periods over the preindustrial Common Era. Nature 571(7766). Springer US: 550-554. DOI: 10.1038/s41586-019$1401-2$.

Neumann FH, Stager JC, Scott L, et al. (2008) Holocene vegetation and climate records from Lake Sibaya, 
Norström E, Norén G, Smittenberg RH, et al. (2018) Leaf wax $\delta$ D inferring variable medieval hydroclimate and early initiation of Little Ice Age (LIA) dryness in southern Mozambique. Global and Planetary Change 170: 221-233.

Otto-Bliesner B, Russell JM, Clark P, et al. (2014) Coherent changes of southeastern equatorial and northern African rainfall during the last deglaciation. Science 346(6214): 1223-1227.

PAGES2k (2013) Continental-scale temperature variability during the past two millennia. Nature Geoscience 6(5): 339-346.

Peel MC, Finlayson BL and McMahon TA (2007) Updated world map of the Köppen-Geiger climate classification. Hydrology and Earth System Sciences 11: 1633-1644.

Quick L, Meadows ME, Bateman MD, et al. (2016) Vegetation and climate dynamics during the last glacial period in the fynbos-afrotemperate forest ecotone, southern Cape, South Africa. Quaternary International 404: 136-149. DOI: 10.1016/j.quaint.2015.08.027.

Quick L, Chase BM, Wundsch M, et al. (2018) A high-resolution record of Holocene climate and vegetation dynamics from the southern Cape coast of South Africa : pollen and microcharcoal evidence from Eilandvlei. Journal of Quaternary Science 33(5): 487-500. DOI: 10.1002/jqs.3028.

Reimer PJ, Bard E, Bayliss A, et al. (2013) IntCal13 and Marine13 Radiocarbon Age Calibration Curves 0-50,000 Years cal BP. Radiocarbon 55(04). Cambridge University Press: 1869-1887. DOI: 10.2458/azu_js_rc.55.16947.

Reinwarth B, Franz S, Baade J, et al. (2013) A 700-year record on the effects of climate and human impact on the southern Cape coast inferred from lake sediments of Eilandvlei, Wilderness Embayment, South Africa. Geografiska Annaler: Series A, Physical Geography 95(4): 345-360. DOI: 10.1111/geoa.12015.

Russel IA, Randal RM, Cole N, et al. (2012) Garden Route National Park, Wilderness Coastal Section, State of Knowledge.

Scott L (1982) Late quaternary fossil pollen grains from the Transvaal, South Africa. Review of Palaeobotany and Palynology 36(3-4). Elsevier: 241-278. DOI: 10.1016/0034-6667(82)90022-7.

Scott L (1996) Palynology of hyrax middens: 2000 years of palaeoenvironmental history in Namibia. Quaternary International 33: 73-79.

Scott L, Neumann FH, Brook GA, et al. (2012) Terrestrial fossil-pollen evidence of climate change during the last 26 thousand years in Southern Africa. Quaternary Science Reviews 32. Elsevier Ltd: 100-118. DOI: 
Slenzka A, Mucina L and Kadereit G (2013) Salicornia L. (Amaranthaceae) in South Africa and Namibia: rapid spread and ecological diversification of cryptic species. Botanical Journal of the Linnean Society 172: $175-186$.

Stager JC, Mayewski PA, White J, et al. (2012) Precipitation variability in the winter rainfall zone of South Africa during the last $1400 \mathrm{yr}$ linked to the austral westerlies. Climate of the Past 8(3): 877-887. DOI: $10.5194 / c p-8-877-2012$.

Stager JC, Ryves DB, King C, et al. (2013) Late Holocene precipitation variability in the summer rainfall region of South Africa. Quaternary Science Reviews 67. Elsevier Ltd: 105-120. DOI: 10.1016/j.quascirev.2013.01.022.

Strobel P, Kasper T, Frenzel P, et al. (2019) Late Quaternary palaeoenvironmental change in the year-round rainfall zone of South Africa derived from peat sediments from Vankervelsvlei. Quaternary Science Reviews 218: 200-214. DOI: 10.1016/j.quascirev.2019.06.014. southern Africa. (May). DOI: 10.1038/srep01767. Caves, Cape Province, South Africa. Quaternary Research 37: 203-213.

Tinner W and Hu FS (2003) Size parameters, size-class distribution and area-number relationship of

Tyson PD (1999) Atmospheric circulation changes and palaeoclimates of southern Africa. South African Journal of Geology 95: 194-201.

Tyson PD and Lindesay JA (1992) The climate of the last 2000 years in southern Africa. The Holocene 2: 271278.

Tyson PD and Preston-Whyte RA (2000) The Weather and Climate of Southern Africa. Cape Town: Oxford University Press. Journal Of Science 96: 121-126. 
714 Van Zinderen Bakker EM (1976) The evolution of late Quaternary paleoclimates of Southern Africa:

$715 \quad$ Palaeoecology of Africa, v 9.

716 Van Zinderen Bakker EM and Coetzee JA (1959) South African Pollen Grains and Spores. III. Cape Town: AA

$717 \quad$ Balkema.

718 Watling R (1977) Trace metal distribution in the Wilderness lakes. Special report FIS 147. Pretoria.

719 Welman WG and Kuhn L (1970) South African Pollen Grains and Spores.

720 Woodborne S, Hall G, Robertson I, et al. (2015) A 1000-Year Carbon Isotope Rainfall Proxy Record from South

721 African Baobab Trees (Adansonia digitata L .). PLoS ONE 10(5). DOI: 10.1371/journal.pone.0124202.

722 Wündsch M., Haberzettl T, Kirsten KL, et al. (2016a) Sea level and climate change at the southern Cape coast,

723 South Africa, during the past 4.2 kyr. Palaeogeography, Palaeoclimatology, Palaeoecology 446 . Elsevier

724 B.V.: 295-307. DOI: 10.1016/j.palaeo.2016.01.027.

725 Wündsch M, Haberzettl T, Meadows M, et al. (2016b) The impact of changing reservoir effects on the 14C

726 chronology of a Holocene sediment record from South Africa. Quaternary Geochronology 36: 148-160.

727 DOI: $10.1016 /$ j.quageo.2016.08.011.

728 Wündsch M, Haberzettl T, Cawthra HC, et al. (2018) Holocene environmental change along the southern Cape 729 coast of South Africa - Insights from the Eilandvlei sediment record spanning the last 8.9kyr. Global and

730 Planetary Change 163. Elsevier B.V: 51-66. DOI: 10.1016/j.gloplacha.2018.02.002. 